\title{
Updating the Clothing Technician Profile through synergies between industry and vocational and educational training
}

DOI: $10.35530 / \mathrm{IT} .071 .06 .1838$

ALEXANDRA CARDOSO

PEDRO NERO GUIMARÃES

ANA PAULA DINIS

ALEXANDROS KOUKOVINIS

\author{
JORGE DOMENECH-PASTOR \\ ALMUDENA SEGADO \\ MIHAELA DASCALU \\ SABINA OLARU
}

\section{ABSTRACT - REZUMAT \\ Updating the Clothing Technician Profile through synergies between industry and vocational and educational training}

The importance of the textile and clothing sector in the European manufacturing industry, particularly in terms of the economy and employability, is very representative and crucial. To act upon urgent need felt by the textile and clothing industry and qualification gap, the CosTUmE project, in alignment with the Skills Agenda for Europe, created and updated the Clothing Technician profile and skills, facilitating the mobility of qualified people in the EU.

This paper presents several aspects concerning the field and desk research developed in order to map the qualifications needs and the Work Based Learning Practices (WBL) in the textile and clothing sector. Also, this work presents the tools developed in order to enable people to make better career choices in UE and help them to find higher quality jobs and improve their life chances: Clothing Technician profile and qualification, ECVET Matrix, Tutorial guide for EU mobility and Training package.

Keywords: clothing, technician, profile, education, labour market

\section{Actualizarea profilului Tehnicianului îmbrăcăminte prin sinergii între industrie și formare profesională}

Importanța sectorului de textile și de îmbrăcăminte în industria prelucrătoare europeană, în special în ceea ce privește dezvoltarea economică și capacitatea de angajare, este reprezentativă și crucială. Pentru a acționa în funcție de nevoile urgente resimțite de industria textilă și de îmbrăcăminte și de lipsa de calificare, proiectul CosTUmE, în conformitate cu Agenda de competențe pentru Europa, a creat și actualizat Profilul și calificarea Tehnicianului îmbrăcăminte, facilitând mobilitatea persoanelor calificate în UE.

Această lucrare prezintă aspecte referitoare la cercetarea de teren și documentară realizată în scopul identificării nevoilor de calificare și a practicilor de învățare la locul de muncă (WBL) în sectorul de textile și de îmbrăcăminte. De asemenea, această lucrare prezintă instrumentele dezvoltate pentru a le permite oamenilor să facă alegeri profesionale mai bune în UE, să își găsească locuri de muncă de calitate superioară și să-și îmbunătățească șansele în viață: profilul și calificarea Tehnicianului îmbrăcăminte, Matricea ECVET, Ghidul pentru mobilitatea în UE și Pachetul de formare.

Cuvinte-cheie: îmbrăcăminte, tehnician, profil, educație, piața muncii

\section{INTRODUCTION}

According to Davis, in today's knowledge-based society, where intellectual capital is an organization's most competitive asset, learning is serious business [1]. The importance of the textile and clothing sector in the European manufacturing industry, particularly in terms of the economy and employability, is very representative and crucial. But despite the enormous employment potential, the sector is unattractive to young people and lacks skilled labour. As referred by European Union, 2017, "textile and clothing sector faces a low attractiveness level, which causes difficulties in attracting new employees, especially younger workers, feeding the already significant skills' gaps among the entire sector's supply chain" [2].

Fast technological change, competitiveness and the growing number of workers close to retirement age require an attentive and active sector, to respond to the challenges in a concerted and dynamic way. Knowledge and skills thus become key factors for the sustainable development of the sector and anticipating skill's needs as well as promoting cooperation between industry and vocational and educational training is critical.

According to Helyer, in a rapidly evolving, highly technological world employees increasingly need to develop skills categorized by these various elements [3]. Vocational education and training have been adapting to a changing society, where the need for knowledge is strong.

In Portugal, Spain and Romania the VET system offers several profiles/qualifications in the clothing field, which are disproportionate or insufficient to accomplish today's companies needs and challenges: quick response capability, high quality of the products, eco-friendly solutions, digital competences, I\&D+I, work-based learning methodologies for workers. 
These challenges require human resources with new (technical and transversal) competences and qualifications.

To face such challenges and act upon urgent need felt by the textile and clothing industry and qualification gap, we designed the CosTUmE project, in alignment with the Skills Agenda for

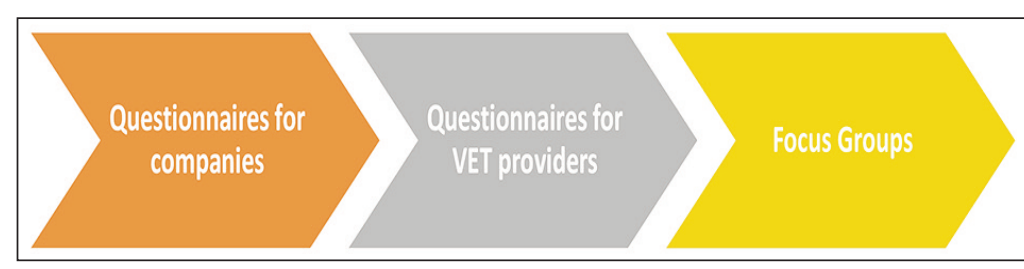

Fig. 1. Field-based research tools Europe, in order to:

- Identify needs, trends and patterns in demands for skills and jobs (skills intelligence) for T\&C sector;

- Improve the attractiveness, quality and relevance of training in the clothing area;

- Create and update a Clothing Technician profile and skills more visible and comparable facilitating the mobility of qualified people in the EU;

- Increase the textile and clothing sector attractiveness and capture of talents, contributing, at the same time, to increase the employability of young people;

- Produce information to enable people make better career choices in UE and help them to find higher quality jobs and improve their life chances;

- To reinforce networking, partnerships and VET policy coherence among different stakeholders at European, regional and country levels among project implementation and after the end of the project.

Following the above challenges, the CosTUmE project was implemented between the three countries, which were united under 2 years of structured work in Key Action 3 of the Erasmus+ program. The extensive effort of the consortium and a great number of consultations with key stakeholders of the sector provided the answers that the EU field needs towards the revitalisation of the clothing sector.

\section{METHODOLOGY}

\section{Desk \& Field Research}

The main objective of the current research was to do an in-depth analysis and a vast fieldwork carried closely with textile and clothing stakeholders from the three countries involved (Portugal, Spain and Romania), to map the qualifications needs and the Work Based Learning Practices (WBL) in the textile and clothing sector.

In the desk-based research, the different partners compiled important information on the different profiles related to the clothing technician profile, to compare common competences, modules and training units. In this research it was also compiled information regarding the European and National Qualifications Framework and relevant competent entities, as well as the WBL good practices by country.

Field-based research aimed to collect field evidences and validate assumptions from the desk research within the textile and clothing sector at national and EU level on:

- validation with companies' representatives that the existing Clothing Technicians' profile is not suitable for the new demands of the sector;

- identify the new competences that should integrate the Clothing Technician training curricula.
In the field-based research, it was carried out questionnaires for companies and VET providers (figure 1). In the three countries, we had 95 surveys answered by companies (which in total represent 10.083 workers) from the clothing sector and 38 surveys answered by VET providers.

In the past 5 years, companies have been adopting different strategies since the number of companies who had deceased, increased or maintained its workforce, are similar. However, majority of respondents foresees an increase in their workforce in the upcoming 5 years, which explains the difference between the number of companies who hired new employees after their VET qualification, and those who are looking for new employees (figure 2).

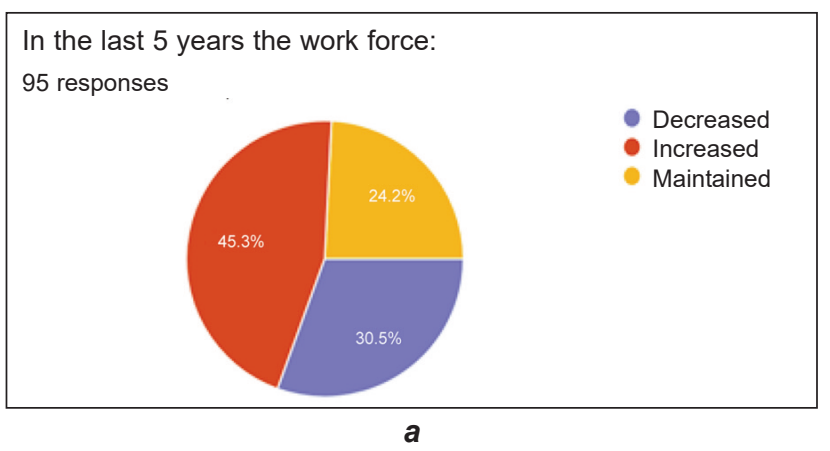

Did you employ a new employee/s just after completing a vocational or apprentice school in last year?

95 responses

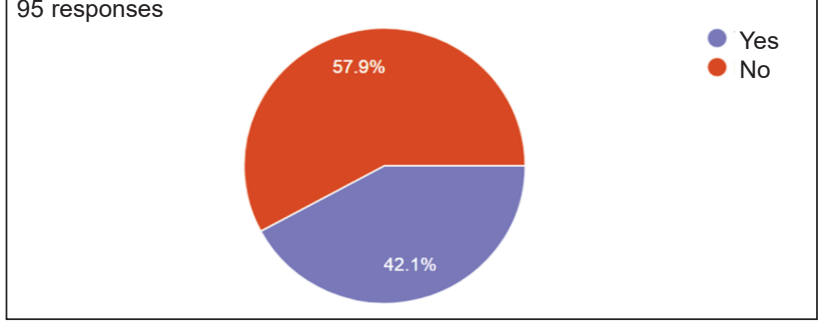

b

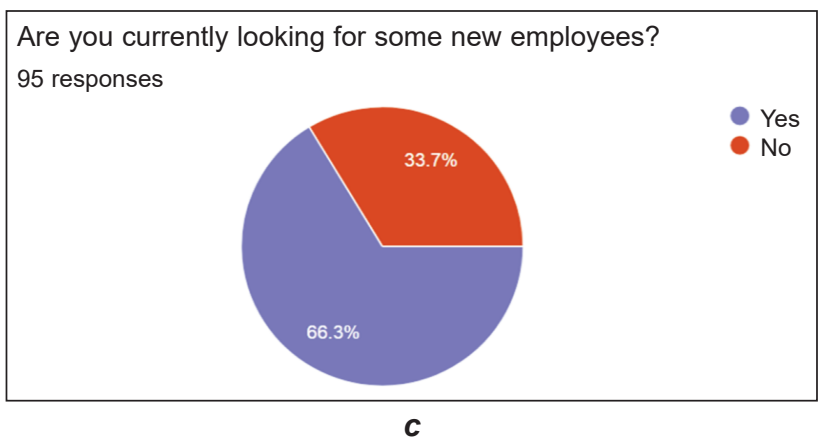

Fig. 2. Companies' strategies for employment: $a$ - workforce evolution; $b$ - new employees hiring; $c$ - new employees searching 
From the following emergent challenges select the most important for this industry. 95 responses

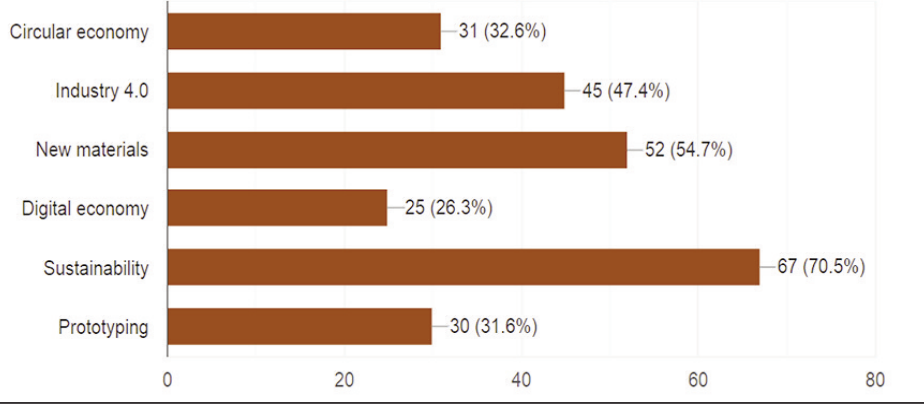

a

From the following emergent challenges select the most important for this industry. 38 responses

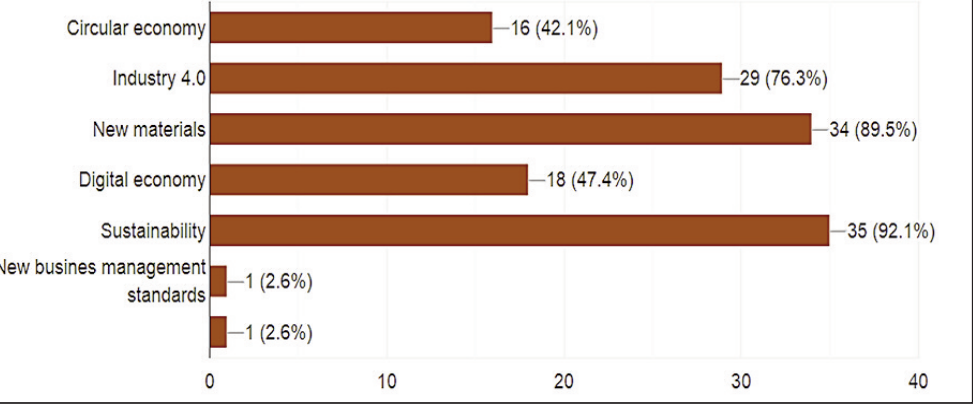

Fig. 3. Emergent challenges: a - companies' opinion; $b$ - VET providers' opinion

The following urgent challenges were appointed: sustainability, use of new materials in products, digitization and industry 4.0, replacement of older workers, low attractivity of youngers, lack of specialized training offer and trainings/internship programmes too short or do not provide the expected results (figure 3 ). The top 5 relevant technical competencies appointed by companies were: "interpret technical sheets and procedure manuals", "in depth knowledge of the production process", "organization of the production process", "develop technical patterns", "elaboration and control of time norms during the operative process" (figure 4).

In the top 5 relevant technical competencies appointed by VET providers, we also found "ensure quality and technical standards", "integrate the norms of safety, hygiene, health and environmental protection in the exercise of professional activity", "manufacture, modification, adjustment machines". and repair of garments/products", "operate different production machines" (figure 5).

Companies appointed "teamwork", "communication and oral skills" and "work management" as the three most relevant transversal competencies. VET providers also have included "foreign language" in this list (figures 6 and 7).

\section{Focus groups}

The results of the surveys were validated and discussed in three focus group sessions, held in the three countries, with the participation of 39 people, of which 29 represented companies or VET providers external to the project.

In these focus group sessions, new technical competences were identified: "knowledge of production equipment settings", "participates in solving all technical problems in the production process", "use pattern design software for clothing", "identifying and anticipating problems through market research", "knowing the safety rules for operating the machines and protect the workers", "knowing the parameters and the characteristics for operating the

New transversal competences were also identified: ability to "learning and assimilation of information" and to "adapt to repetitive and routine tasks".

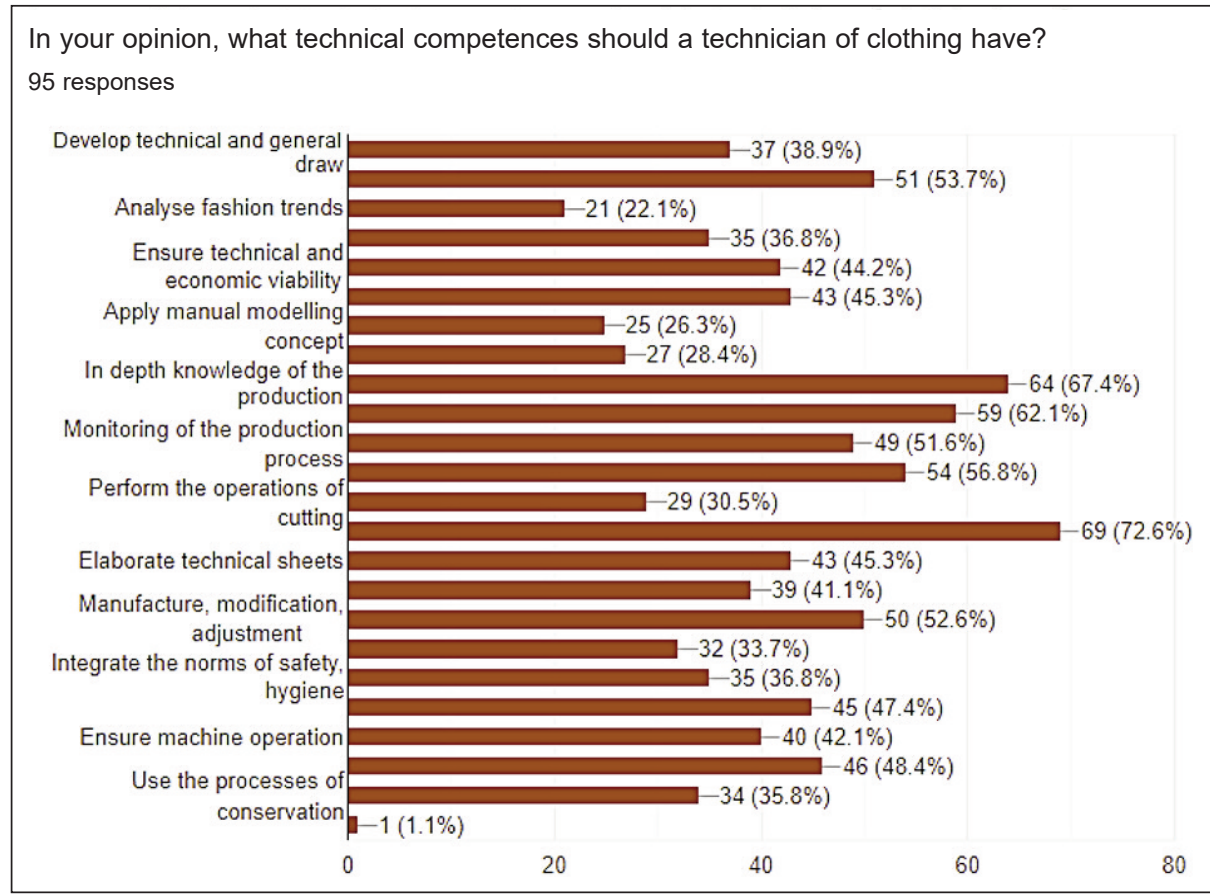

Fig. 4. Relevant technical competencies appointed by companies 
Obviously, the list of competences identified as important were balanced with the existing resources and, above all, with the number of hours provided for the training of this technician.

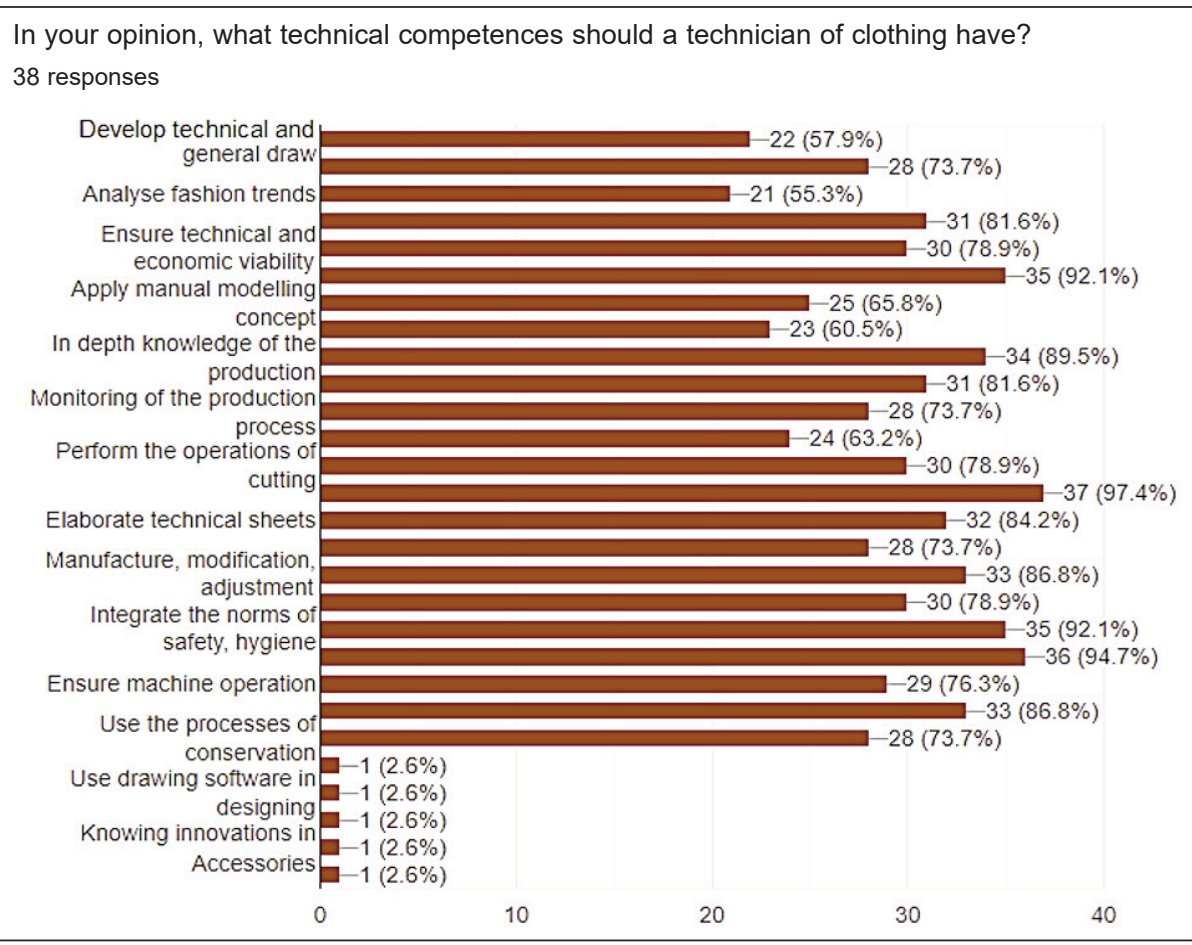

Fig. 5. Relevant technical competencies appointed VET providers

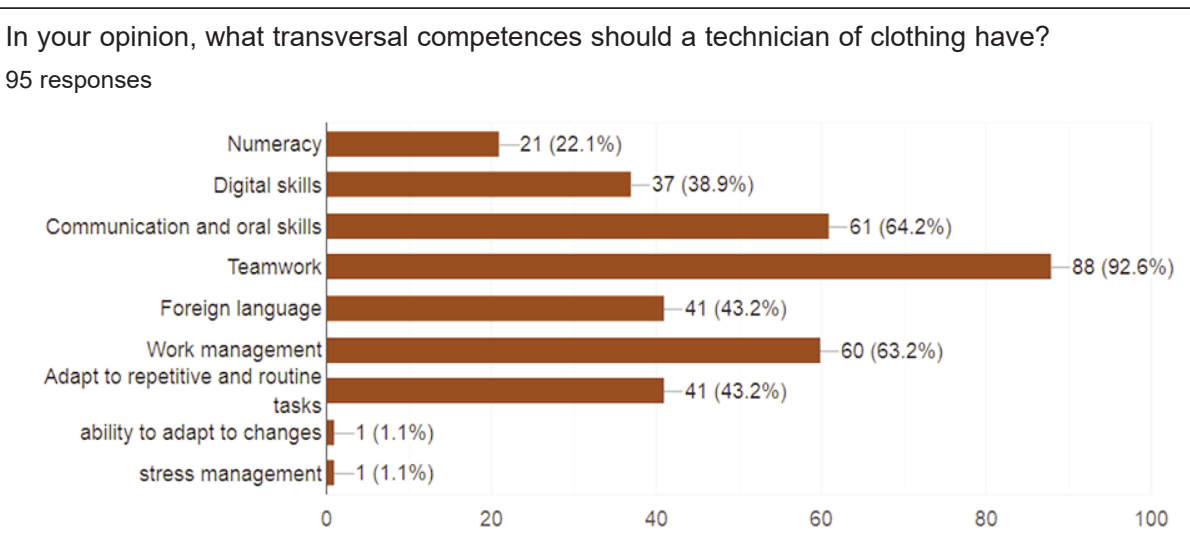

Fig. 6. Relevant transversal competencies appointed by companies

In your opinion, what transversal competences should a technician of clothing have? 38 responses

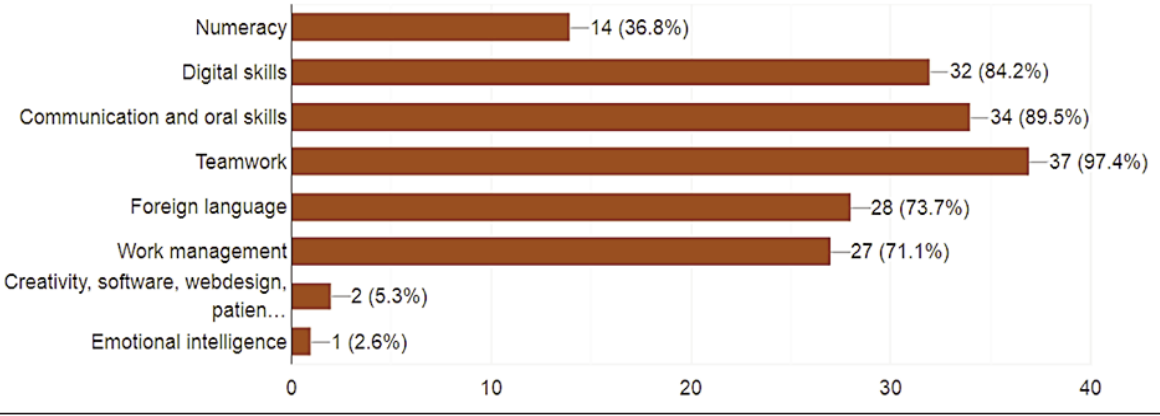

Fig. 7. Relevant transversal competencies appointed by companies
In this focus group it was also discussed possible measures to attract youngers to the sector, having been listed the importance of the recognition and valorization of the profession, the adjustment of leadership style by supervisors and superiors, the improvement of working conditions and working environment, as well as the importance of dual training.

\section{RESULTS AND DISCUSSIONS}

\section{Clothing Technician}

Profile and Qualification

The profile answers to a lack of training that exists in this area considering the needs that the companies have of qualified Clothing Technicians with competences in the scope of the management and organization of the work, modelling, sewing, new materials industry 4.0 technologies, etc.

Based on the information received from stakeholders during the networking sessions organised in the three countries (Portugal, Spain and Romania), the partners elaborated a new Clothing Technician Profile and Qualification. In general, the profile integrated transversal contents related with soft skills, technical contents and apprenticeship.

The training curriculum for profile followed the subsequent structure:

- Identify the output profile (table 1):

- Identify transversal contents;

- Transform specific professional competences into units of knowledge;

- Identification of the objectives per each unit;

- Identification of the contents per each unit;

- Identification of the training hours per each training;

- Establish an assessment system of learning;

- Allocate ECVET points for each unit. 


\begin{tabular}{|l|c|l|}
\hline \multicolumn{3}{|c|}{ CLOTHING TECHNICIAN PROFILE } \\
\hline \multirow{4}{*}{$\begin{array}{l}\text { Competence } \\
\text { Units }\end{array}$} & 1 & Planning the production \\
\cline { 2 - 3 } & 2 & Organizing the production \\
\cline { 2 - 3 } & 3 & Monitoring the production process \\
\cline { 2 - 3 } & 4 & Executing technical sheets \\
\cline { 2 - 3 } & 5 & Performing procedure manuals \\
\cline { 2 - 3 } & 7 & $\begin{array}{l}\text { Using pattern making tools } \\
\text { (manual and digital) }\end{array}$ \\
\cline { 2 - 3 } & 8 & $\begin{array}{l}\text { Onderating manufacturing machines } \\
\text { garments and accessories }\end{array}$ \\
\cline { 2 - 3 } & 9 & $\begin{array}{l}\text { Using quality and technical } \\
\text { standards }\end{array}$ \\
\hline
\end{tabular}

The contents and the duration of the units defined were different in each partner country, because the partners followed the national structure of the professional profiles. However, it was ensured the recognition and transferability of the profile/qualification.

The profile was developed in accordance to EQF and taking into consideration the existing ECVET recommendations. By combining study and work, apprenticeships and work-based learning (WBL) certainly offered to trainees an important opportunity to acquire work experience while enhancing skills in close alignment with employer needs [4]. Workbased learning could help to reduce skills mismatch and ease transition from education to work. In this sense, the profile integrated contents in real work context. With learning outcomes and Work-based learning methodology, the consortium ensured that learners acquire the knowledge, skills and competences with direct relevance for the labour market.

According to Helyer, the modern workforce requires workers with adaptable and entrepreneurial attitudes, who are willing to learn continuously [3]. Table 2 presents some of the main benefits of the WBL for trainees, companies and educational organizations.

During pilot training action, trainers evaluated the new profile/qualification and discussed the whole training concept, the scheme and the methodologies defined to undertake the new Clothing Technician Profile. Based on their recommendations, the Clothing Technician Profile was improved.

\section{ECVET Matrix}

The ECVET Matrix promoted the recognition of a new professional profile and qualification by the national regulatory entities that meet EQF requirements $[5,6]$. The matrix includes precise guidelines with the profile match process in Portugal, Spain and Romania and describes the following aspects:

- framework/regulatory Entities for the European/ National Qualifications Framework;

- purpose of level descriptors;

- ECVET system in participating countries [7];

\begin{tabular}{|l|l|}
\hline \multicolumn{2}{|c|}{ BENEFITS OF WORK-BASED LEARNING (WBL) } \\
\hline $\begin{array}{l}\text { Learnerl } \\
\text { trainee }\end{array}$ & $\begin{array}{l}\text { Opportunity to align theoretical learning } \\
\text { with the expectations of the future profes- } \\
\text { sion. Allows the acquisition of a deeper } \\
\text { knowledge through experimentation. }\end{array}$ \\
\hline \multirow{5}{*}{$\begin{array}{l}\text { It allows to have better informed and more } \\
\text { effective workers, thus improving the } \\
\text { overall efficiency of the company and } \\
\text { ensuring its competitiveness in the future. } \\
\text { It can significantly contribute to the } \\
\text { development of the workforce in sectors } \\
\text { where there are identified skills gaps, or } \\
\text { where occupations or sectors are among } \\
\text { the least favoured. }\end{array}$} \\
\hline $\begin{array}{l}\text { Training programmes become more } \\
\text { attractive to trainees. } \\
\text { In addition, they make it possible to create } \\
\text { richer and more structured training pro- } \\
\text { grammes promoting sustained learning. } \\
\text { partnerships with companies can also } \\
\text { provide access to technologies that would } \\
\text { not otherwise be possible. }\end{array}$ \\
\hline
\end{tabular}

- distributed UC for the point of view of knowledge, skills, responsibility and autonomy, learning outcome, assessment criteria and output;

- profile match for the point of view of qualification designation, area, level of qualification, body awarding the qualification or competent authority, credit system, quality assurance procedures and qualification documents.

ECVET points are a numerical representation of the overall weight of learning outcomes in a qualification and of the relative weight of units in relation to the qualification. Allocation of ECVET points to a qualification is based on using a convention according to which 60 points are allocated to the learning outcomes expected to be achieved in a year of formal full time VET [8].

To define the duration of the profile and the allocation of ECVET points, the partnership has developed a method of analysis based on importance degree: labour market, complexity and training hours (figure 8). The matrix is a useful document that can help other VET providers in definition of new profiles.

\section{Tutorial guide for EU mobility}

Mobility and exchange are relevant and contribute substantially to the development of the European education system, in terms of quality and networking $[9,10]$. Mobility is an excellent way for students to improve the use of a foreign language, autonomy, responsibility, social competences and develop different knowledge related with clothing area in different context which will improve the employment prospects.

The European Union recognizes the importance to support cross-border mobility of learners and workers and lifelong learning across Europe and supports the mobility through mobility programmes, through 


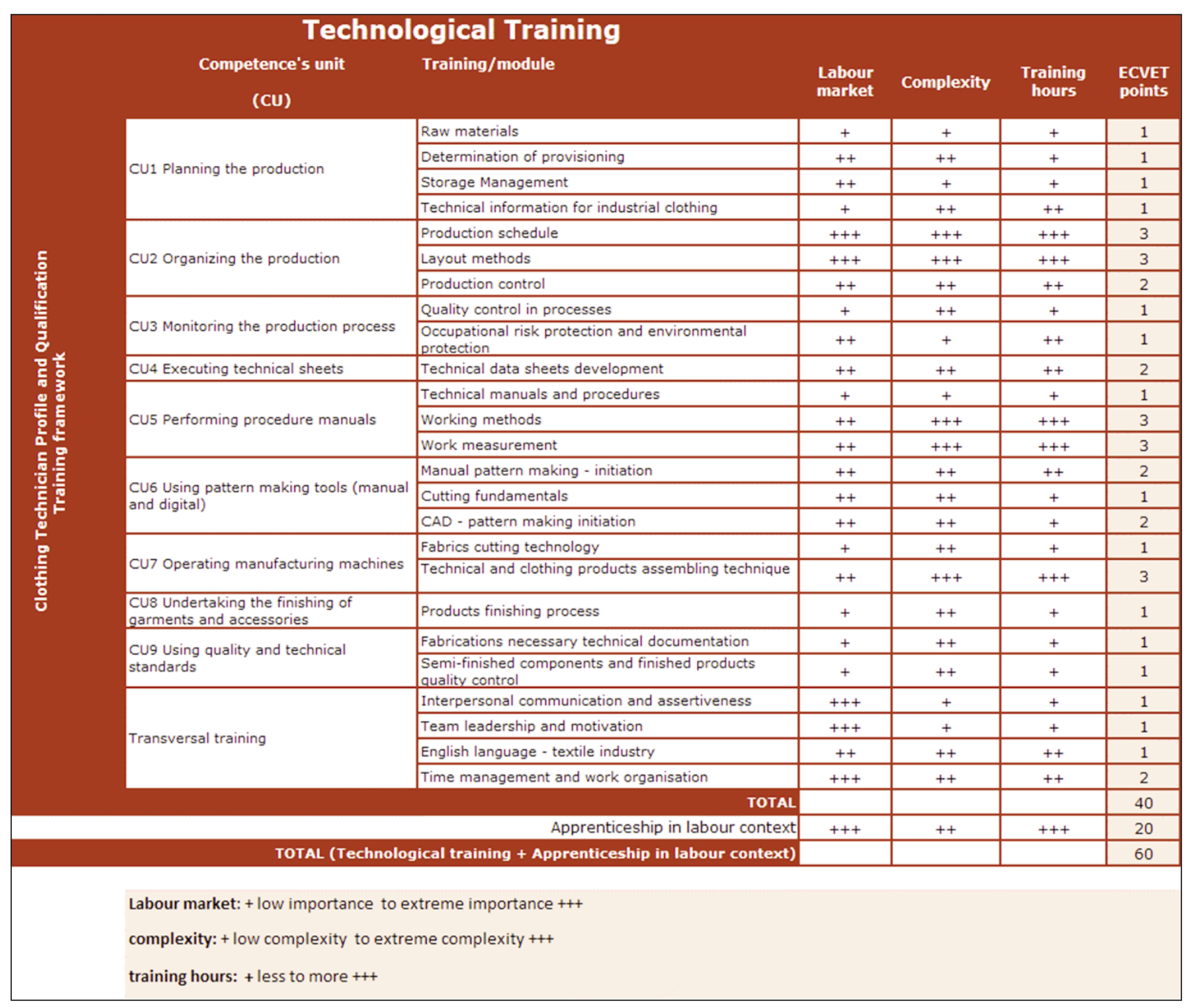

Fig. 8. Clothing Technician Profile and Qualification - ECVET points

establishing national centres, the first points of contact for any person or organisation interested in working or learning across Europe.

The Tutorial Guide for mobility aimed to present the importance of mobility across the Europe, the mobility documents, the European and national entities that support mobility and VET providers and companies that are available to host apprenticeships. It is a guidance that may facilitate future mobility processes across the Europe.

In the Clothing Technician Profile the period of apprenticeship was defined in accordance with national specifies. The tutorial guide integrates concrete orientations for VET institutions and students to understand how they can participate in a mobility period. The tutorial guide also includes the contact of different existing VET institutes in the three partner countries, as several contacts from several textile companies that usually host apprenticeships or are open to receiving apprenticeship in future.

The qualification profile should be recognized and validated through Europass, ensuring the principles of European Transparency and Recognition. The tutorial guide offers the main orientation of the mobility, mainly: Europass mobility (registration of any period of time that its holder spent in another European country for education and vocational training purposes (European learning pathway) and Europass Certificate Supplement (for people holding an official vocational education and training certification or equivalent) [11-14]. Therefore, the learners can personalize their training path according to their experience and knowledge.

\section{Training Package about Clothing Technician Profile and Qualification for trainers}

Choosing and applying the most appropriate teaching/training techniques and methods according to the objectives of a training is a crucial factor for learning success. Therefore, it is important to define which methods and techniques are best suited to the objectives, the target audience and the context in which the training takes place.

An active teaching/training method places the learner at the centre of the learning process, creates a favorable environment for learning and is defined by dynamic, creative and collaborative activities. The 
choice of the best techniques makes it possible to encourage the best learning behaviours.

An innovative training package and a concerted train the trainers for delivering the Professional Profile and Qualification have been performed. On one side, the main aim was to support and provide resources to trainers of the textile and clothing sector in order to empower them in delivering this new Clothing Technician profile, and on the other side implementing a training action for trainers.

In this sense, the tasks performed are divided in 2 phases, in the first phase all resources have been developed by all partners in order to define the training contents which will be taught in this new profile focusing in aspects defined in previously work such as "Planning the production", "Organizing the production", "Monitoring the production process", "Executing technical sheets", "Performing procedure manuals" or "Operating manufacturing machines".

The methodologies and resources presented in this toolkit serve as inspiration and guide for the implementation of the Clothing Technician profile/qualification by each VET provider.

The training package is structured in three parts. The first part presents the Clothing Technician Profile and the relationship between the competence units, the second part presents the main active methodologies of teaching/training, and the last part presents a set of activities consisting of a case study, a group dynamic and a practical case for each competence unit. In total, 27 activities were developed to help future trainers to implement the Clothing Technician Profile and Qualification.

The relationships matrix allows establishing connections within each Competence Unit, among the training modules that it encompasses, and also connections between modules of different Competence Units. In this manner, it can be operationalized the link between contents and objectives of the Competence Unit (blocks of training modules) according to the Clothing Technician profile. It can be also operationalized the schedule stemming from the connections definition, e.g., precedences and simultaneity between modules (figure 9 ).

Once all contents were developed by each partner, the train the trainer's action was carried out in every country, so at the end three training actions were performed. The results were gathered to improve the work done. In each country, this Train the Trainers action was implemented by 13 trainees in Portugal, by 10 trainees in Spain and by 11 in Romania. The results showed that above $80 \%$ of trainees consider

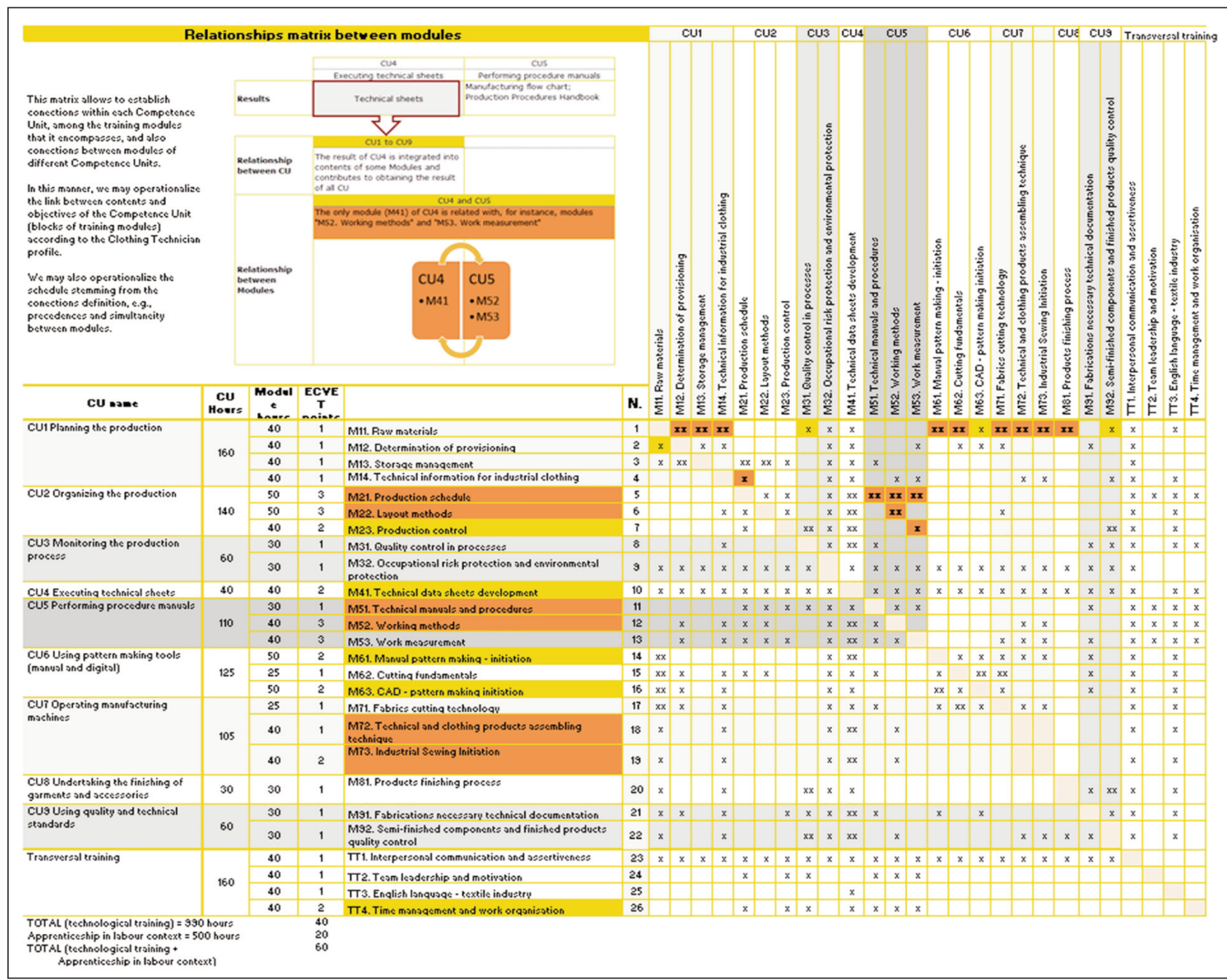

Fig. 9. Relationships matrix between Competence Units 
the training action good or very good, and most of them as adequate in duration. As an improvement point, trainers suggested to reduce some Cutting modules and introduce a new module regarding Industrial Sewing. In addition, almost all trainees considered that the design and the didactic resources developed were of very high quality and very useful for teaching.

The results presented above can be accessed at https://clothingtechnician.eu/.

\section{IMPACT AND SUSTAINABILITY}

A dedicated work enclosed a great deal of outreach actions from the partners to disseminate the results achieved. Even early in the start of CosTUmE, communication strategies were conscripted that made sure that the progress was shared, the opportunities of engagement have been well known and the results of the project accessible to every interested individual and organisation. This extensive effort managed to mobilise more than 13 Representatives from the national authorities, 209 Representatives of the textile and clothing companies, 172 VET experts and 98 Sectorial social partners to take part into the CosTUmE activities and in real time contribute to the development and validation of the answers to the challenges identified. Moreover, the partnership made sure to implement wide events for the dissemination of the results, and kept making extensive use of the online media to gain the interest of the target groups in global level and break the barriers of distance.

All the above, allowed CosTUmE to reach the finalisation of the project work and conquer two major achievements that elevate its impact:

- the officialisation of collaboration between partners and the National Agencies for the Qualifications;

- the recognised contribution with an updated skillset and programs to the EU field of the clothing sector. More than ever, CosTUmE remains available and "ON", accessible at https://clothingtechnician.eu/ to provide its invaluable results to every interested, and keep alive the ever-growing networking around the initiative.

\section{CONCLUSIONS}

In recent years, teaching methodologies have been increasingly improved, so there is a growing range of different options available to VET institutions. This reality has led to passive learning approaches becoming less valued.

\section{(1) COSTUME}

Also in the context of COVID19 pandemics, the teaching methodologies are changing learning environments around the world, providing renewed academic performance.

The rapid transformation we are witnessing, be it technological, social, or in values, among others, has driven the need for adjustment and improvement. If on one hand we have a society looking for the most successful student/trainee to help in becoming more competitive on economic grounds, on the other hand we have students/trainees with a will to know and to be a part of this process. This reality has led managers/directors and teachers/trainers to rethink teaching and learning models and methods.

During the desk and field research, it has been identified a clear need to reschedule the learning plan of the professionals trained in this field of expertise and to implement more WBL practices, something that the trainers and the people in the industry see as vital for a satisfactory subsequent incorporation to the industry. Also, it was concluded that companies should also start or reinforce the following actions as a way of attracting youngers to the sector:

- Recognition and valorisation of the profession;

- Adjustment of leadership style by supervisors and superiors;

- Dual training;

- Improvement of working conditions (working hours, salaries, permanent contracts, pay leave conditions, provide benefits in products, life-work balance);

- Improvement of working environment (greater proximity between employees, employees feel good and valued, team buildings, rewarding ideas for improving the workplace, recreation areas).

Finally, companies should demonstrate commitment and involvement in these challenges and create an environment \& conditions that will bring out the best of the employees and make pressure on the authorities competent so that effective measures are adopted.

\section{ACKNOWLEDGMENTS}

The research presented in this paper was prepared by the CosTUmE consortium. Funds support this work are from Erasmus+ KA3 Support for Policy Reform, Clothing Technician Profile Update via Education - CosTUmE Project, Contract 597854-EPP-1-2018-1-PT-EPPKA3-VET$\mathrm{JQ}$, funded by European Commission.

This project has been funded with support from the European Commission. This publication [communication] reflects the views only of the author, and the Commission cannot be held responsible for any use which may be made of the information contained therein.

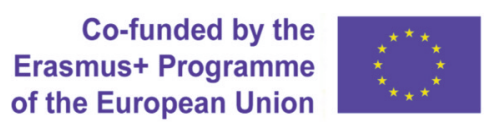

\section{REFERENCES}

[1] Davis J.e Davis, A., Effective Training Strategies - A Comprehensive Guide to Maximizing Learning in Organizations, San Francisco: Berret - Koehler Publishers Inc., 1998 
[2] European Union, BLUEPRINT FOR SECTORAL COOPERATION ON SKILLS Textile/Clothing/Leather/Footwear (TCLF). Responding to skills mismatches at sectoral level A key action of the New Skills Agenda for Europe, Luxembourg: Publications Office of the European Union, 2017, https://doi.org/10.2767/803019

[3] Helyer, R., Learning through reflection: the critical role of reflection in work-based learning (WBL), In: Journal of Work-Applied Management, 2015, 7, 1, 15-27, https://doi.org/10.1108/JWAM-10-2015-003

[4] Work-based learning toolkit, Available at: https://www.wbl-toolkit.eu/index.php?id=13 [Accessed March 2019]

[5] CEDEFOP, Analysis and overview of NQF level descriptors in European countries, Luxembourg: Publications Office. Cedefop research paper, 2018, 66, Available at: http://www.cedefop.europa.eu/files/5566_en.pdf [Accessed April 2019]

[6] CEDEFOP, National qualifications framework developments in Europe 2017, Luxembourg: Publications Office. Cedefop information series, 2018, 4163, Available at: http://www.cedefop.europa.eu/en/publications-andresources/publications/4163 [Accessed April 2019]

[7] European Commission, Education and Culture (2011). The European Credit System for Vocational Education and Training ECVET. Get to know ECVET better Questions and Answers, 2011, Available at: https://www. cedefop.europa.eu/files/ECVET_QUESTION_ANSWERS_Feb_2011_en(download_ID_17648).pdf [Accessed October 2019]

[8] EUR-LEX, Recommendation of the European Parliament and of the Council of 18 June 2009 on the establishment of a European Credit System for Vocational Education and Training (ECVET) (Text with EEA relevance), 2009, Available at: https://eur-lex.europa.eu/legal-content/EN/ALL/?uri=CELEX:32009H0708\%2802\%29 [Accessed October 2019]

[9] European Council, Fair labour mobility in the EU, Available at: https://www.consilium.europa.eu/en/policies/labourmobility/\# [Accessed October 2019]

[10] CEDEFOP, Terminology of European education and training policy, Second edition, Luxembourg: Publications office of the European Union, 2014, Available at: https://www.cedefop.europa.eu/files/4117_en.pdf [Accessed October 2019]

[11] European Comission, CEDEFOP, Europass, Europass Mobility, Available at: https://europass.cedefop.europa.eu/ documents/european-skills-passport/europass-mobility [Accessed October 2019]

[12] European Comission, CEDEFOP, Europass, About Europass, Available at: https://europass.cedefop.europa.eu/ about-europass [Accessed October 2019]

[13] European Comission, CEDEFOP, Europass, National Europass Centres, Available at: https://europass.cedefop. europa.eu/about/national-europass-centres [Accessed October 2019]

[14] European Comission, CEDEFOP, Europass, Working in Europe, Available at: https://europass.cedefop. europa.eu/learning-and-working-in-europe/working [Accessed October 2019]

Authors:

ALEXANDRA CARDOSO ${ }^{1}$, PEDRO NERO GUIMARÃES ${ }^{2}$, ANA PAULA DINIS ${ }^{3}$, ALEXANDROS KOUKOVINIS $^{4}$, JORGE DOMENECH-PASTOR ${ }^{5}$, ALMUDENA SEGADO $^{6}$, MIHAELA DASCALU ${ }^{7}$, SABINA OLARU $^{8}$

${ }^{1}$ CITEVE - Centro Tecnológico das Industrias Têxtil e do Vestuário de Portugal, Vila Nova de Famalicão, Portugal

${ }^{2}$ MODATEX - Centro de Formação Profissional da Indústria Têxtil, Vestuário, Confecção e Lanifícios, Porto, Portugal e-mail: pedro.guimaraes@modatex.pt

${ }^{3}$ ATP - Associação Têxtil e Vestuário de Portugal, Vila Nova de Famalicão, Portugal e-mail: ana.paula.dinis@atp.pt

${ }^{4}$ INOVA+, Matosinhos, Portugal

e-mail: alexandros.koukovinis@inova.business

${ }^{5}$ AITEX - Textile Research Institute, Alcoy, Spain e-mail: jdomenech@aitex.es

${ }^{6}$ ASECOM - Asociación de Empresas de Confección y Moda de la Comunidad de Madrid, Madrid, Spain e-mail: comercioexterior@asecom.org

${ }^{7}$ ASTRICO NORD-EST Association, Savinesti, Romania e-mail: office@astricone.eu

${ }^{8}$ National Research \& Development Institute for Textiles and Leather, Lucretiu Patrascanu no.16, 030508, Bucharest, Romania e-mail: sabina.olaru@incdtp.ro

Corresponding author:

ALEXANDRA CARDOSO

e-mail: acardoso@citeve.pt 